\title{
Surgical Treatment for the Refractory Allergic Rhinitis: State of the Art
}

\author{
Antonino Maniaci ${ }^{1, *(\mathbb{D})}$, Milena Di Luca ${ }^{1}$, Ignazio La Mantia ${ }^{1}$, Calogero Grillo ${ }^{1}$, \\ Caterina Maria Grillo ${ }^{1}$, Elio Privitera ${ }^{1} \mathbb{D}$, Claudio Vicini ${ }^{2}$, Giannicola Iannella ${ }^{2,3}{ }^{\mathbb{D}}$, \\ Claudia Renna ${ }^{1}$, Vittoria Bannò ${ }^{1}$, Francesca Migliore ${ }^{1}$ and Salvatore Cocuzza ${ }^{1}$ \\ 1 Department of Medical and Surgical Sciences and Advanced Technologies “GF Ingrassia”, ENT Section, \\ University of Catania, 95123 Catania, Italy; milenadiluca@gmail.com (M.D.L.); igolama@gmail.com (I.L.M.); \\ grillo@unict.it (C.G.); grillo.caterinamaria@gmail.com (C.M.G.); priviteraelio@gmail.com (E.P.); \\ claudia.renna93@gmail.com (C.R.); vittoriabanno@gmail.com (V.B.); \\ francesca.migliore258@gmail.com (F.M.); s.cocuzza@unict.it (S.C.) \\ 2 Department of Head-Neck Surgery, Otolaryngology, Head-Neck, and Oral Surgery Unit, 47121 Forlì, Italy; \\ claudio@claudiovicini.com (C.V.); giannicola.iannella@uniroma1.it (G.I.) \\ 3 Department of 'Organi di Senso', University “Sapienza”, 00185 Rome, Italy \\ * Correspondence: tnmaniaci29@gmail.com
}

Received: 24 December 2020; Accepted: 18 February 2021; Published: 25 February 2021

check for updates

\begin{abstract}
Nasal obstruction is a frequent disorder that interferes with the daily patient's quality of life. The key element in the pathophysiology of the disorder is the inferior turbinate hypertrophy related to multiple conditions such as allergic rhinitis (AR). Many patients are managed using conventional drug therapies such as antihistamines, decongestants, and intranasal steroid sprays, anticholinergic agents, mast cell stabilizers, and desensitizing vaccines. When traditional therapy failed to relieve AR symptoms, surgical inferior turbinate reduction (ITR) is indicated. A vast variety of surgical techniques have been reported in the literature for AR such as resectioning, coagulating, and laser procedures. We aimed to revise all surgical options in AR management. We confirm that no ideal standard technique for turbinate reduction has been developed so far regarding the multitude of different surgical procedures. Furthermore, no prospective and comparable long-term studies are present in the literature; it is challenging to recommend evidence-based surgical techniques.
\end{abstract}

Keywords: nasal surgery; allergy; turbinate surgery; allergic rhinitis; radiofrequency ablation; laser; neurectomy

\section{Introduction}

Nasal obstruction is a common disease that interferes with the daily patient's quality of life [1].

The key element in the pathophysiology of the disorder is the inferior turbinate hypertrophy related to multiple conditions such as allergic rhinitis (AR), pseudo-allergy, and non-allergic rhinitis eosinophilic, and iatrogenic syndrome [2-4].

The inferior turbinates (IT) execute a central function in modulating airflow and nasal resistance through vasodilation and consequent nasal obstruction, congestion, and discomfort [5].

Signs of AR result consequent to an inhaled allergen are characterized by a T helper 2 response and higher serum IgE levels and eosinophilia [6,7].

The interaction between allergens and nasal mucosa is mediated by antigen-presenting cells (dendritic cells, APCs) and naïve T cells [8].

Consequently, the T lymphocytes change into T helper type 2 (Th2) cells and produce interleukin 4 (IL-4), IL-5, and IL-13, promoting the B cell phenotype producing related IgE. Subsequently, IgE bound 
to the distinct receptors (Fc\&RI) of mast cells, and basophils cause cell activation; we illustrated Il5-13 pathways between eosinophils and mast cells in Figure 1 [9].

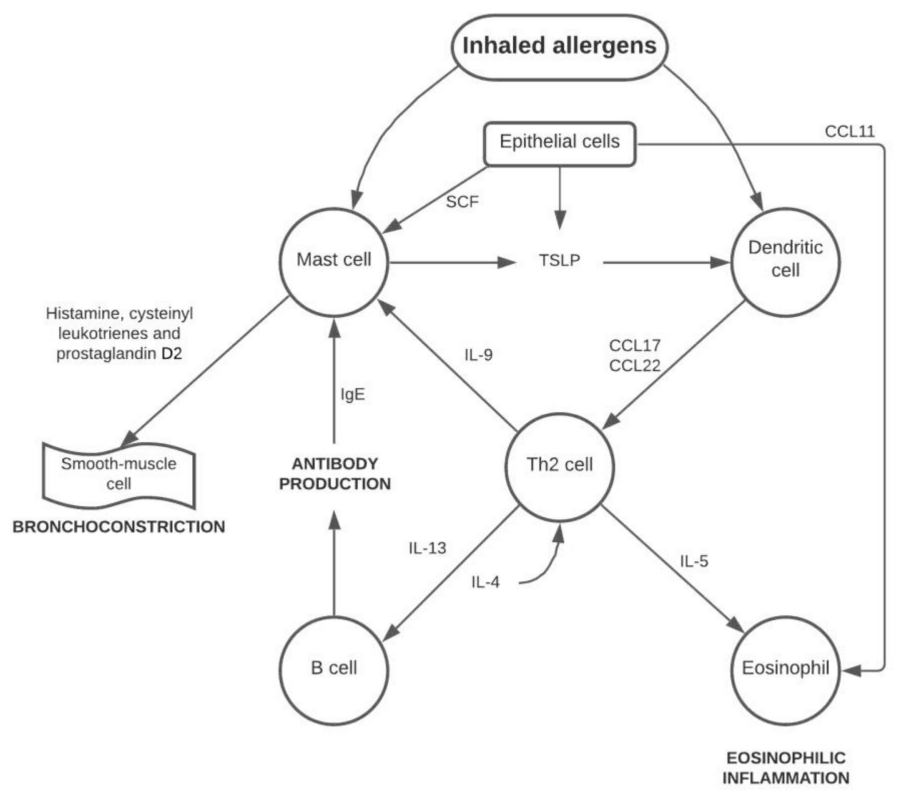

Figure 1. Immunophlogistic cascade of the allergic pathway. Abbreviations: CCL11, C-C motif chemokine 11; CCL17, C-C motif chemokine 17; CCL22, C-C motif chemokine 22; IL-4, Interleukin 4; IL-5, Interleukin 5; IL-9, Interleukin 9; IL-13, Interleukin 13; SCF, stem cell factor; TSLP, Thymic stromal lymphopoietin.

Re-exposure to sensitized allergens leads to cascade disorders and allergic rhinitis (RA) manifestations. Many patients are treated with the use of conventional drug therapies such as antihistamines, decongestants and intranasal steroid sprays, anticholinergic agents, mast cell stabilizers, and desensitizing vaccines [10].

Although medical treatment is often useful in restoring good nasal breathing, sometimes nasal obstruction becomes disabling, leading inexorably to use and abuse local nasal spray with a consequent high risk of iatrogenic outcomes.

When traditional therapy fails to reduce AR symptoms, inferior turbinate reduction (ITR) is one of the simplest procedures made for the surgical treatment of nasal blocking. A series of techniques concerning reducing turbinates are currently feasible as cryosurgery, electrocautery, laser turbinectomy, partial or total turbinectomy, and Vidian's neurectomy give different results. Due to direct manipulation of the mucous membrane during surgery, adverse accidents such as bleeding, pain, crusting, smell change, dry nose, and synechia can happen [11-14].

Eosinophils, mast cells, and other immune cells play a critical role in allergic rhinitis: surgical treatment help prevent eosinophil and immune cell-mediated allergic diseases. Mladina et al. in 78 patients treated with turbinate surgery found improvements in $90 \%$ of cases of post-operative cytologic findings both in allergic and non-allergic subjects [15].

Moreover, Cassano et al. stated symptoms' reduction in 51.4\% of allergic rhinitis [16]. In contrast, the authors found improvements in $42.8 \%$ with non-allergic rhinitis with eosinophils (NARES) and $64.3 \%$ of mast cells with eosinophils (NARESMA).

The primary goals of turbinal surgery, according to the clinical practice guidelines (2015), are based on observational studies, with a preponderance of benefit over damage, evaluating:

- $\quad$ Quality of life (QoL) and nasal breathing improvement [17];

- Symptomatic gain achieved through various mechanisms: exuberant mucous tissue reduction determines a reduction of the contact points for the allergens present in the inhaled air [9]; 
- Reduction in the use of drugs with better patient compliance;

- Preservation of the nasal mucosa using techniques that maintain mucociliary activity unchanged;

The scar tissue that develops inside the submucosal layer leads to damage of both to the vascularization and the glandular structures, preventing their regrowth through fibrosis with the reduction of the amount of specific IgE present on the nasal mucosa and of eosinophils [18].

Mucosa's preservation that remains perfectly functioning allows, after the ITH procedure, both the maintenance of enough air space to support air's humidification and purification and the maintenance of airways physiological resistance.

The purpose of the narrative review performed was to list and better clarify the specific characteristics of each surgical technique described in the literature to date in the treatment of AR refractory to medical therapy (Figure 2).

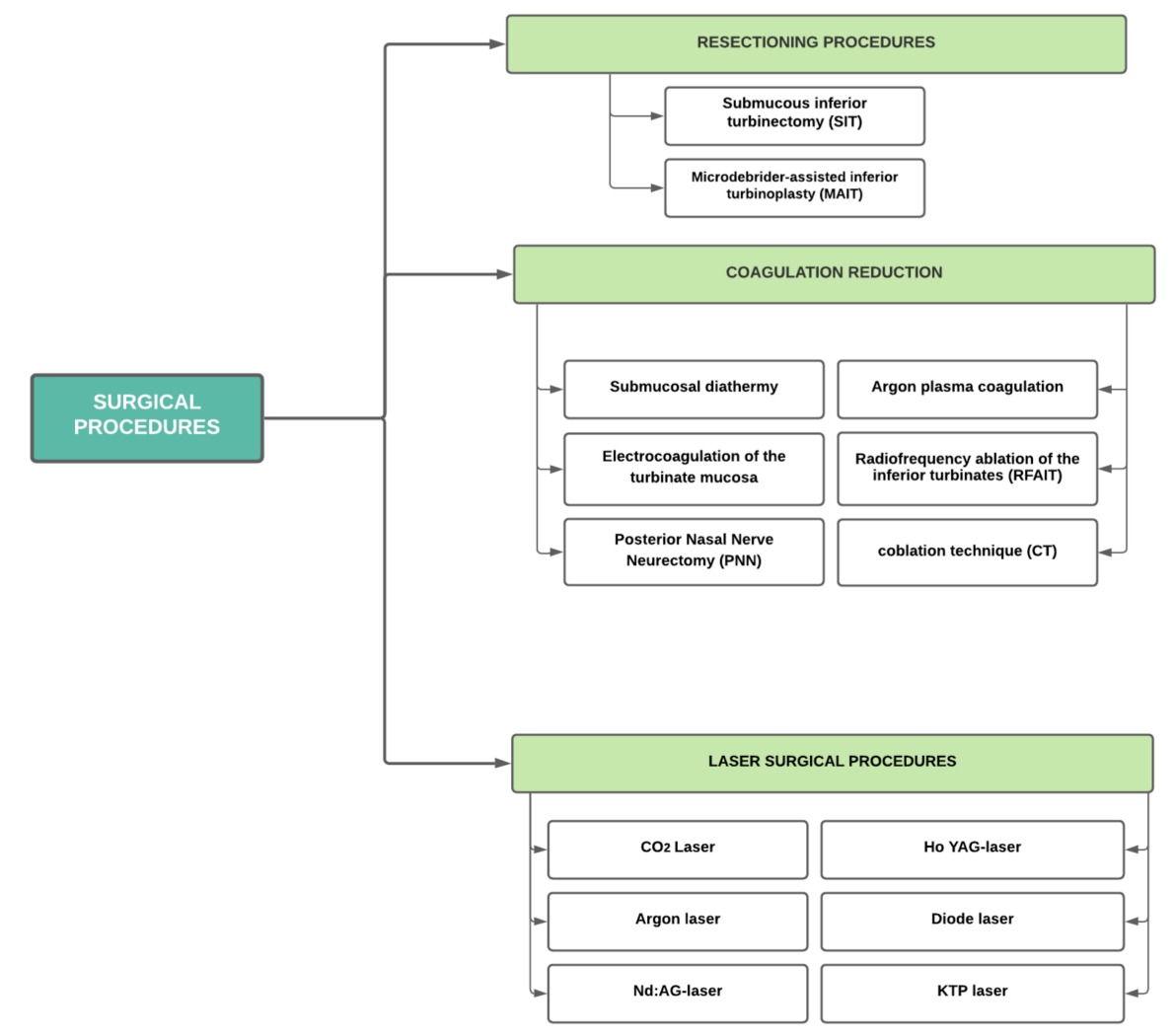

Figure 2. Main surgical techniques currently described in the literature in the surgical treatment of allergic rhinitis. Abbreviations: PNN, posterior nasal nerve neurectomy; APC, Argon plasma coagulation; RFAIT, radiofrequency ablation of the inferior turbinate; CT, coblation technique; Ho:YAG-laser, Holmium:yttrium-aluminium-granat-laser; Nd:YAG-laser, Neodymium: yttrium aluminium garnet laser; KTP laser, Potassium titanyl phosphate laser.

\section{Surgical Therapy of the Inferior Turbinate in AR}

Techniques for turbinate reduction show that there is no absolute technique that supports long-term success but that the outcome is mainly linked to complications that occur in the short-long term (Table 1) [19]. 
Table 1. Main studies identified in the literature and principal features described.

\begin{tabular}{|c|c|c|c|c|c|c|}
\hline Reference & Year & Study Design & $\begin{array}{l}\text { Features (Allergic Patients vs. } \\
\text { Control Group) }\end{array}$ & Follow-Up Time & Objective Evaluation ( $p$-Value) & $\begin{array}{c}\text { Subjective } \\
\text { Evaluation ( } p \text {-Value) }\end{array}$ \\
\hline Türk & 2018 & $\begin{array}{c}\text { Prospective } \\
\text { non-randomized }\end{array}$ & RFA (23 allergic vs. 36 non allergic) & 3,6 months & $\begin{array}{c}\text { Nasal obstruction }(<0.001) \text {; Acoustic } \\
\text { rhinometry }(<0.001)\end{array}$ & $\operatorname{VAS}(<0.001)$ \\
\hline De Corso & 2016 & Prospective & $\begin{array}{l}\text { RFA (114 allergic vs. } 191 \\
\text { non-allergic) }\end{array}$ & $\begin{array}{c}1 \text { month, yearly for } 5 \\
\text { years }\end{array}$ & & NOSE $(<0.05)$ \\
\hline Di Rienzo Businco & 2014 & $\begin{array}{l}\text { Randomized } \\
\text { controlled trial }\end{array}$ & QMR (145 treated vs. 145 control) & 3 months & $\begin{array}{l}\text { Active anterior rhinomanometry }(<0.05) \text {; } \\
\text { Rhinoendoscopy clinic score }(<0.05) ; \text { STT } \\
\text { (No statistically different from pretreatment) }\end{array}$ & $\begin{array}{l}\text { SNOT-22 }(<0.05) \text {; VAS } \\
(<0.05)\end{array}$ \\
\hline Gunhan & 2011 & $\begin{array}{l}\text { Prospective } \\
\text { randomized }\end{array}$ & RFT (28) vs. INS (27) & 12 months & Active anterior rhinomanometry $(<0.003)$ & $\begin{array}{c}\text { VAS }(<0.05) ; \text { RQLQ } \\
(<0.05)\end{array}$ \\
\hline Ravichandran & 2020 & $\begin{array}{l}\text { Randomized } \\
\text { controlled trial }\end{array}$ & $\begin{array}{c}\text { KTP (105) vs. Diode (104) [allergy } \\
\text { not specified] }\end{array}$ & 1, 2 days, 1,3 months & $\begin{array}{l}\text { STT (Severely prolonged, statistically } \\
\text { insignificant. 'Need more time to } \\
\text { follow-up') }\end{array}$ & NOSE $(<0.001)$ \\
\hline Gupta & 2018 & $\begin{array}{l}\text { Descriptive } \\
\text { cross-sectional }\end{array}$ & Diode (60) & 3 months & & VAS (significant) \\
\hline Vijayakumar & 2016 & Descriptive & КТР (30) & 1 week, 1,3 months & $\begin{array}{l}\text { STT (Return to preoperative value by the } \\
\text { end of } 3 \text { months) }\end{array}$ & SNOT $(<0.0001)$ \\
\hline Parida & 2013 & Prospective & Diode (45) [allergy not specified] & 1 week, $1,3,6$ months & $\begin{array}{l}\text { STT (Return to preoperative value by the } \\
\text { end of } 6 \text { months) }\end{array}$ & $\operatorname{VAS}(<0.001)$ \\
\hline Sroka & 2007 & $\begin{array}{l}\text { Retrospective } \\
\text { non-randomized } \\
\text { comparative }\end{array}$ & $\begin{array}{c}\text { Ho:Yag or Diode (44 allergic vs. } 46 \\
\text { non allergic) }\end{array}$ & 6 months, 3 years & Active anterior rhinomanometry $(<0.001)$ & $\begin{array}{l}\text { Subjective } \\
\text { questionnaires ( } 85 \% \\
\text { improvement) }\end{array}$ \\
\hline Lee & 2013 & Prospective & MAIT (60) & $3,6,12$ months & Acustic rhinometry $(<0.05)$ & VAS $(<0.05)$ \\
\hline Chen & 2008 & Prospective & MAITL (80) vs. SR (80) & $1,2,3$ years & $\begin{array}{l}\text { Active anterior rhinomanometry }(<0.05) \text {; } \\
\text { STT }(<0.05)\end{array}$ & $\operatorname{VAS}(<0.05)$ \\
\hline Liu & 2009 & Prospective & MAIT (60) vs. RAIT (60) & 6 months, 1, 2, 3 years & $\begin{array}{c}\text { Active anterior rhinomanometry }(<0.05) \text {; } \\
\text { STT }(<0.05)\end{array}$ & $\operatorname{VAS}(<0.05)$ \\
\hline Huang & 2006 & Prospective & MAIT (50) & 1 year & Active anterior rhinomanometry $(<0.001)$ & RQLQ $(<0.005)$ \\
\hline Nagalingeswaran & 2020 & Retrospective & PNN Selective Resection (212) & $\begin{array}{c}2 \text { weeks, } 1,2,6,12 \\
\text { months }\end{array}$ & ND & SNOT-22 $(<0.001)$ \\
\hline Krespi & 2018 & Prospective & Diode Laser PNN (32) & 1,3 months & ND & TNSS $(<0.001)$ \\
\hline Lai & 2017 & Retrospective & $\begin{array}{l}\text { Diode laser-assisted VN (43) vs. } \\
\text { Cold instrument (75) }\end{array}$ & 6 months & ND & $\operatorname{VAS}(<0.001)$ \\
\hline Tan & 2012 & Prospective & $\begin{array}{c}\text { Bilateral VN (93) vs. Partial inferior } \\
\text { turbinectomy and/or septoplasty (51) } \\
\text { vs. Control group (92) }\end{array}$ & 6 months, 1,3 years & ND & $\begin{array}{l}\text { VAS }(<0.05) ; \text { RQLQ } \\
\quad(<0.05)\end{array}$ \\
\hline
\end{tabular}


In a comprehensive review, Mol and Huizing described 13 different surgical techniques for ITR [17].

Based on these criteria, turbinate reduction studies only meet the terms of evidence levels 3 and 4 : only two studies have yet reached evidence level 2 where long-term follow-ups of 6 and 5 years were conducted, respectively $[10,20]$.

Each technique is judged on two basic criteria:

- how effective the method was in decreasing hypersecretion from respiratory obstruction, headaches, and sneezing episodes;

- side outcomes occurring in the short and long term.

It would be a mistake to concentrate entirely on expanding the nasal passages in endoscopic findings, rhinomanometry, and acoustic rhinometry.

A wider nasal cavity does not necessarily mean the nose works better: It is now known that total turbinectomy is nearly out-of-date and radical resection of the inferior turbinate can cause atrophic rhinitis, chronic osteitis, or paradoxical nasal obstruction. The following complication is the hallmark of empty nose syndrome (ENS).

In order to systematize the different surgical techniques, it is possible to outline a subdivision of techniques into three surgical groups: lateralization or lateropexy (it is named only for the sake of completeness), resection, and coagulation procedures.

\section{Resectioning Procedures}

Resection and surgical reduction of the inferior turbinates are techniques that date back to the early nineteenth century. Total turbinectomy (full turbinate separated directly at the base of the lateral nasal wall) and partial turbinectomy (mucosal lamina and bones resected in the front third of the turbinate) are not, to date, widely used due to the obvious disadvantages that can be applied meeting.

In literature, there is a highly inappropriate success rate that can vary between $0 \%$ and $89 \%$ [21]. Turbinectomy is not compatible with the primary goal of preserving nasal function; some patients suffered from atrophic rhinitis and secondary ozaena with symptoms of nasal dryness, crusting, bleeding, pain, and headache [22]. Talmon et al., performed, over 6 years, 357 total inferior bilateral turbinectomies in patients with chronic nasal obstruction: 351 patients $(98.3 \%)$ underwent the procedure without any significant complication, six patients $(1.7 \%)$ experienced postoperative bleeding that required emergency surgery [22].

Huizing and de Groot referred to a total turbinectomy as a "nasal crime": they, therefore, suggest never to remove more than half of the inferior turbinate [23].

\subsection{Submucous Inferior Turbinectomy (SIT)}

Many surgeons prefer submucous inferior turbinectomy (SIT) as a resective method performed on the anterior third of turbinate through a vertical incision of the mucous membrane of the turbinate head. In this way, IT nasal mucosa and submucosa remain uninjured, and the turbinal volume is reduced without alternating functionality.

Passali et al. performed a randomized comparative study on 382 patients with 4-year follow-up where it was shown that submucosal resection linked with lateralization of IT conferred long-term results regarding better nasal breathing, faster healing of mucociliary clearance, and the local secretion of IgA [10].

Mori et al. explained submucosal inferior turbinectomy (SIT) inhibited allergic reactions in the IT of patients with AR improving the QOL in patients with severe allergic rhinitis: [24] this study group reported long-term results over a 5-year follow-up period, evaluating a significant improvement in both symptomatology and subjective mucosal response after exposure to inhalant allergens, after submucosal resection in a classic way. The mean total nasal symptom score (maximum 9) was significantly lower at one year after surgery $(7.5+/-1.6$ vs. $1.8+/-1.8, p<0001)$ compared with 
before surgery and a significant improvement in nasal symptoms was noted at the 3-year $(2.8+/-2.3$, $p<0.0001)$ and 5-year $(3.3+/-1.6, p<0.0001)$ time points [24].

Submucosal reduction of the inferior turbinate is generally well tolerated with few long-term side effects and provides beneficial effects for RA patients.

\subsection{Microdebrider-Assisted Inferior Turbinoplasty (MAIT)}

Microdebrider is an essential tool in the field of nasosinus surgery; it was introduced in daily use in turbinal surgery as MAIT (microdebrider-assisted inferior turbinoplasty).

The MAIT technique can be performed in a dual-modality both intraturbinally and on the surface of the external turbinate with an endoscope in order to remove the IT abundant tissue. In the intraturbinal MAIT, after a small submucosal incision, microdebrider performs a millimeter resection, and extraturbinal MAIT can accurately extract the hypertrophic piece. Benefits include real-time aspiration with precise tissue removal $[25,26]$.

Lee et al. showed that extraturbinal MAIT appeared more powerful for long-term relief of allergic symptoms than intraturbinal techniques [28]. Sixty patients diagnosed with perennial AR were chosen, 30 patients were treated with intraturbinal MAIT (group 1) and the other 30 with extraturbinal MAIT (group 2). All symptoms decreased significantly in both groups at 3, 6, and 12 months; above all in group 2 at 12 months $(p<0.001)$ [27].

Although the microdebrider is a very useful technique for ITR in AR, the bony portion of the turbinate is spared. In this case, the addition of out fracture or lateropexy can be considered [28].

Chen et al. (2008) evaluated the long-term effectiveness of microdebrider-assisted inferior turbinoplasty with lateralization (MAITL) compared to submucosal resection for HIT. They showed MAILT appears to be as efficient as submucosal resection at decreasing nasal symptoms and limiting total nasal resistance and saccharin transit times for more than three years in patients with perennial AR. Compared to classic submucosal resection, the data in the literature suggest improved mucociliary time thanks to less surgical trauma and less tissue removed [28].

\section{Coagulating Reduction}

Coagulation procedures are a set of methods based on deep high-frequency heat (electromagnetic waves in the frequency range of 106-1010 Hz) that determine the formation of wounds: during their healing, the venous sinusoids, present in the submucosal, sclerotize slowly, causing in the long term, the volumetric reduction of the turbinate.

\subsection{Submucosal Diathermy (SMD)}

Submucosal diathermy (SMD) is a coagulating procedure based on monopolar or bipolar caustics use: the needle electrode inserted into submucosal space, starting at the level of the turbinate body up to its extremity, with an application during $5 \mathrm{~s}$ [29].

Fradis et al. evaluated the short-term outcomes of SMD underlying good results in $78 \%$ of cases 2 weeks after surgery, but the effectiveness of the procedure was decreased to $76 \%$ two months after surgery. [31] According to their nasal airflow patency, one hundred patients with nasal blocking were subdivided into two groups: 49 patients underwent inferior bilateral turbinectomy (BIT) and 51 patients underwent SMD. All 100 patients were followed for two months after surgery. Two weeks after surgery, the operation's success for nasal obstruction was $96 \%$ for the BIT patients and $78 \%$ for the SMD patients $(p<0.005)$. Both procedures are comparably safe and efficient, helping the chronic nasal obstruction, although SMD is more effective in the short term and could be disappointing on a long-term basis [30].

Another study confirmed long-term results. It was non-encouraging: 533 patients with HIT treated with carbon dioxide (CO2) and (Nd: YAG) laser techniques and compared their long-term results with those of submucosal diathermy. Among the different techniques, compared to submucosal diathermy, both laser methods produced better long-term results: two years postoperatively, the overall 
benefit rate, as defined by patient satisfaction, was $79.6 \%$ for the CO2 Laser, $68.3 \%$ for the Nd: YAG laser, and $36 \%$ for submucosal diathermy [31].

\subsection{Electrocoagulation of the Turbinate Mucosa}

In the IT electrocoagulation, the inferior turbinate's medial wall is cauterized in an anteroposterior direction using bipolar forceps. The heat generated by coagulation leads to fibrosis and necrosis first, scarring of the turbinate mucosa a second time [32].

This electrocoagulation type is a rather risky procedure as it consciously compromises mucosal integrity. After the procedure, both atrophic and/or metaplastic changes of the mucosa and submucosa could be found up to a loss of efficacy of mucociliary transport.

A prospective study evaluated the effectiveness of electrocautery, cryotherapy, and radiofrequency techniques, comparing patients' reply to these three surgical modalities of ITR [34]: 90 patients manifesting nasal blocking with or without allergic symptoms, at the end of 12 months, $56.6 \%$ of patients treated with electrocautery and $56.6 \%$ of patients treated with cryotherapy registered $75 \%$ improvement in nasal obstruction, whereas $59.99 \%$ of patients treated with radiofrequency showed $100 \%$ gain. So, radiofrequency showed a better personal increase in nasal obstruction when compared to cryotherapy and electrocautery [33].

\subsection{Posterior Nasal Nerve Neurectomy (PNN)}

Golding-Wood introduced Vidian neurectomy in 1961 to relieve severe nasal hypersecretion in vasomotor rhinitis [34]. He proposed the vidian nerve through Caldwell-Luc's procedure, removing the posterior and some of the antrum's medial wall to uncover the pterygopalatine fossa, opening of the vidian canal, aiming for parasympathetic resection of the vidian nerve [34].

The posterior nasal nerve is a peripheral branch from the sphenopalatine ganglion, which starts the nasal cavity through a separate hole 4 to $5 \mathrm{~mm}$ below the sphenopalatine foramen/ethmoid crista after the nerve bifurcation into the lacrimal nerve. The posterosuperior nasal nerves innervate the upper and middle turbinates and foramina; other parasympathetic nerve fibers of the nose branch off from the greater palatine nerve and enter the nasal cavity through the canaliculi of the perpendicular plate of the palatine bone such as the posterior-inferior nasal nerves, these nerves innervate the meatus and the inferior turbinate [35].

Endoscopic endonasal surgery's development replaced the classic Vidian neurectomy with posterior nasal nerve neurectomy (PNN) [36]. This surgery overcame the complications of Vidian neurectomy and is minimally invasive.

Kawamura et al. reported in 2000 on the effectiveness of posterior nasal neurectomy linked with submucosal inferior turbinectomy for AR patients who had severe hyperreactive nasal symptoms refractory to medical treatment, in which neural bundles of the posterior nasal nerve were selectively cut or cauterized at the sphenopalatine foramen using an endoscopic nasal approach, leaving the secretory nerve fibers to the lacrimal glands intact [36].

In 2007, Kikawada reported an endoscopic PNN technique that resets the posterior nasal nerve near the sphenopalatine arteries and can control intraoperative bleeding under direct vision. A questionnaire survey was conducted in 94 patients with AR 2 years after surgery evaluating the efficacy of the procedure in about $80 \%$ of cases [37].

A retrospective study conducted in 212 patients with AR symptoms evaluated the endoscopic resection of PNN and mini-inferior turbinoplasty technique [38]. Patients were considered two weeks before and after surgery, followed up from 1st, 2nd, 6th, and 12th month postoperatively through a subjective evaluation with sinonasal outcome questionnaire SNOT-22: the mean SNOT-22 score after the procedure also significantly reduced from 50 to 8 at 12 months. In addition, 39.6\% (84/212) of the patients had outlived almost free from all symptoms without medication at 12 months ( $p$-values $<0.01$ ) [38]. 


\subsection{Argon Plasma Coagulation (APC)}

Argon plasma coagulation (APC) uses a high-frequency monopolar caustic which, through the ionized argon gas (the so-called plasma) conducts the current flow without direct contact with the mucosa, with a distance of $2-10 \mathrm{~mm}$ between the applicator tip and the fabric, reaching temperatures up to $3000{ }^{\circ} \mathrm{C}$. This thermocoagulation involves forming a zone of local necrosis that during the wound's healing results in a cicatricial reduction of the surrounding mucosa.

In 2003, Bergler suggested much evidence on APC use in head and neck surgery. In the literature, reduction of turbinates, removal of leukoplakia or laryngeal papilloma, and treatment of epistaxis in patients with genetic telangiectasia are described [39].

In a prospective study of 121 patients (AR in 24 patients, vasomotor rhinitis in 75 cases, and chronic decongestant nose spray in 22 patients) with a follow-up period of 16 months, Bergler et al. concluded $76 \%$ of patients felt better nasal breathing after one week. After six weeks, the turbinates were re-epithelialized by healthy mucosa in $63 \%$ of the patients. After 12 months, $83 \%$ of the patients stated that they had better nasal airflow than preoperatively [40].

The most crucial advantage of APC turbinoplastly is the chance of performing a procedure without direct connection, while cryosurgery or electrocautery requires direct contact of the applicator with the IT [41].

Gierek et al. evaluated 100 patients (70 patients with bilateral hypertrophy of turbinates and 30 patients control group without breathing problems). Rhinomanometric parameters, clearance of saccharine test results, and cytological examinations were analyzed, obtaining results confirming the high effectiveness of APC for inferior turbinates reduction [41].

The use of inert gas argon during APCt results in a lack of smoke formation, which in the case of the use of electrocautery or Laser may hinder the precise orientation in the operative field.

Edyta Jura-Szołtys et al. evaluated bronchial asthma symptoms control in patients with chronic rhinitis after argon plasma coagulation turbinectomy (APCt) [42]. The effect of APCt was assessed in 47 adults with drug-resistant chronic rhinitis and bronchial asthma 3-month post-procedure. Subjective improvement of nasal blockage three months after APCt was recognized in $87 \%$ and of rhinorrhoea in $75 \%$ of patients. Rhinomanometry showed a $219 \pm 19 \mathrm{~cm}^{3} / \mathrm{s}$ increase of flow and $0.75 \pm 0.06 \mathrm{~Pa} / \mathrm{cm}^{3} / \mathrm{s}$ reduction of resistance. The predominance of patients with insufficient bronchial asthma control decreased from $79 \%$ to $4 \%$. The decrease was associated with diminished frequency of eosinophils ( $20 \%$ in nasal cytology from $83 \%$ pre-procedure to $28 \%$ in the follow-up). Reduction in drug-resistant rhinitis symptoms after APCt is followed by significant improvement of asthma control [42].

\subsection{Radiofrequency Ablation of the Inferior Turbinates (RFAIT) and Coblation Technique}

Radiofrequency ablation of inferior turbinates (RFAIT) is a minimally invasive surgical technique that reduces turbinate size and decreases nasal obstruction with the direct application of high frequency (temperature about $75^{\circ} \mathrm{C}$ ), inducing mucosa's thermonecrosis [43].

RFAIT is a widely used thermal ablation technique to reduce nasal obstruction symptoms, acting on reducing the volume of the lower turbinates [43].

This technique has the advantage of being an outpatient procedure that can be performed quickly and can be performed under local anesthesia, increasing the patient's quality of life [44].

Overall, encouraging long-term results are reported. A prospective study (Lin et al. 2010) was performed on 146 patients with allergic rhinitis refractory to medical therapy who underwent RFAIT. Visual analog scale (VAS) was used to assess the allergic symptoms, including nasal obstruction, rhinorrhea, sneezing, after RFAIT at 6 months and 5 years postoperatively: the mean VAS score changed from 5.90 (2.79) to 3.79 (2.97) for rhinorrhea; from 5.15 (2.77) to 3.50 (2.77) for sneezing; from 3.67 (3.03) to 2.41 (2.30) for itchy nose; and from 2.94 (3.02) to 2.02 (2.42) for itchy eyes (all $p<0.001$ ) [14].

The long-term evaluation showed that RFAIT for AR or NAR appeared to improve the smell, reduce nasal resistance, and had subjective benefits in $82 \%$ of patients in a long time (60 months) [45]. 
Turk et al. showed radiofrequency seems to be an adequate and safe treatment option for ITH of 59 patients with AR or non-allergic rhinitis ( 23 with AR, 36 with NAR), providing a better perception of all nasal symptoms (nasal obstruction, rhinorrhea, nasal itching, sneezing) measured by VAS score: 43. All parameters were analyzed as obstruction degree, acoustic rhinometry; VAS score reduced after a third and sixth month in a statically significant way $(p<0.001)$ [46].

De Corso et al., in their study, confirmed the insignificant distress and low risk of side effects of RFA, showing good efficiency of the method in the preponderance of patients for at least 36 months after surgery. A total of 305 patients (114 allergic and 191 non-allergic) who underwent RFAIT completed the NOSE-scale questionnaire pre-and postoperatively after 1 month and yearly for 5 years. Postoperatively, there was a notable improvement in nasal stuffiness, nasal obstruction, and mouth breathing $(p<0.05)$. In the following 2 years, it was perceived a worse temporal trend in terms of recurrence rate, and in particular in AR patients with a significant difference vs. NAR patient $(p<0.05)$ [47].

Coblation technology is based on the concept of molecular activation electrodissection acting on the submucosal layer. This technique has achieved rising popularity in recent years and is mainly adopted in the pediatric population thanks to greater patient compliance and less pain $[48,49]$.

Sim'eon et al. studied the effectiveness of Coblator (Arthro-Care Corporation, Austin, TX) on the radiofrequency device in $9 \mathrm{AR}$ patients with a mean age of 12.7 years. Long-term results (6 months) were observed, with a net reduction in nasal resistance and subjective symptoms such as itching, sneezing, hyposmia, and rhinorrhea [49].

RFAIT and coblation procedures are well tolerated with minimal adverse effects and can be performed safely in the operating room or even outpatient.

\section{Laser Surgical Procedures}

The use of lasers in ITH reduction deserves a separate mention. The Laser produces a beam of light that is absorbed from the tissue depending on the wavelength of the laser light. The energy released in this process leads to thermal damage to the fabric. It is also possible to apply laser light pulsed or continuous [50,51].

The goal of laser therapy is to prevent excessive damage to the turbinal mucosa or bone exposure during the turbinates' volumetric reduction. The laser emission can be applied according to linear, spot, anteroposteriorly, or the anterior third of the IT [52].

Actually, there are six several laser methods available: the carbon dioxide laser (CO2), the argon laser, the neodymium: yttrium aluminium garnet laser (Nd: YAG), potassium titanyl phosphate laser (KTP), the diode laser, and the holmium: yttrium aluminium garnet laser (Ho: YAG) [53].

\subsection{CO2 Laser}

The CO2 laser, a gas laser, is the most frequently used laser mode used in head and neck surgery. The laser beam $(9.60-10.60 \mu \mathrm{m})$, given through a surgical microscope, avoids laser power being partially received by the fiberoptic cable: a custom self-retaining nasal speculum permits the surgeon to have both hands free, making laser surgery easier [54].

The published long-term results expose a substantial variety and range between $50 \%$ and $100 \%$. Almost all studies are retrospective, non-comparative and describe different techniques of laser surgery [52].

Testa et al. showed evidence that CO2 laser turbinectomy can positively influence QoL patients with AR and chronic obstructive rhinitis. A total of 308 patients (168 with AR, 140 with chronic rhinitis) were recorded. Laser turbinectomy reconstructed nasal flow and induced a change in total score, which was statistically significant, for specific and general symptoms at the first, second, and third follow-up $(p<0.01)$ [55].

In a prospective study, Takeno et al. described $\mathrm{CO} 2$ laser partial turbinectomy in perennial and seasonal RA patients and noted less pronounced improvement in the seasonal RA group. It used acoustic rhinometry to estimate postoperative differences in nasal passage. Four months after treatment, 
the minimum cross-sectional area and nasal cavity volume had increased, respectively, by $61.7 \%$ and $30.7 \%$ in the perennial $\mathrm{AR}$, and by $30.7 \%$ and $16.2 \%$ in the seasonal group: $\mathrm{CO} 2$ laser therapy may be useful for acute seasonal exacerbations but the effects may not be therapeutic at most until later in the allergy season [56].

\subsection{Argon Laser}

The argon laser is an ion laser with a wavelength of $0.48-0.52 \mu \mathrm{m}$. The argon laser is absorbed by hemoglobin, and this makes it an ideal tool for vascular alterations. It was already used in 1981 for Rendu Osler disease as described by Parkin-Dixon [57].

It has not been widely accepted in turbinal surgery in AR, but we mention it anyway for the sake of completeness of this paper.

\subsection{Neodymium: Yttrium Aluminium Garnet Laser (Nd: YAG-Laser)}

The neodymium: yttrium aluminium garnet laser (Nd: YAG-laser) is a solid-state laser with a wavelength in the infrared field of $1.06 \mu \mathrm{m}$ that can penetrate to a depth of $1 \mathrm{~cm}$. Since the thermal reaction is more significant than other laser systems, it is recommended to limit the energy to $1000 \mathrm{watts} / \mathrm{cm}^{2}$ and reduce the application time by $0.5 \mathrm{~s}$ [58].

Laser light is carried out by employing a flexible fiber under endoscopic vision with or without contact on the mucosal surface. The energy released is absorbed by the submucosal venous plexus causing vasculitis sclerotizes in the exposed area and reduces the volume of the turbinate [59].

Olthoff et al. (1999) used the Nd: YAG Laser by contacting the inferior turbinate in a total of 83 patients with AR and vasomotor rhinitis. After a one-month check-up, an $80 \%$ success rate was found both in the AR group and in the group with vasomotor rhinopathy [60].

Vagnetti et al. carried out a study on 121 patients (30 patients with AR, 91 with NAR) treated with Nd:YAG laser and controlled up to one year. At 1-year follow-up, the complication rate in all our patients treated with this laser technique was very low, and we achieved a steady improvement in nasal patency in 104 patients (85.9\%). The relapse rate was approximately $14 \%$, but it was observed that $65 \%$ of the patients who experienced long-term failure were affected by allergic rhinitis [61].

\subsection{Holmium: Yttrium-Aluminium-Granat-Laser (Ho: YAG-laser)}

The Holmium: YAG (Ho: YAG Laser) solid-state Laser features a wavelength of $2.123 \mathrm{~nm}$ and a reduced infiltration depth of $0.4 \mathrm{~mm}$. Its minimum thermal energy decreases the turbinate volume, causing the formation of fibrin and scabs that heal in a period ranging from 3 to 6 weeks [62].

Sroka et al. compared Ho: YAG Laser with diode laser in two groups of patients after six months and 3-year long-term follow-up. In the first therapy group, a total of 80 patients (allergic rhinitis $46 \% \mathrm{vs.}$ vasomotor rhinitis 54\%) were treated by a pulsed Ho: YAG laser, and the second group of 113 patients (allergic rhinitis $52 \%$ vs. vasomotor rhinitis $48 \%$ ), instead, were treated by diode laser. Three years after laser surgery, a subjective improvement of nasal airflow had been described by the patients in $67.5 \%$ after Ho: YAG- and in $74.4 \%$ after diode laser treatment [63].

In a retrospective review between Ho: YAG and submucosal diathermy, Rejali evaluated 19 patients with AR (8 patients treated with Laser vs. 11 treated with diathermy). Effectiveness in the laser $(n=8)$ and diathermy group $(n=11)$ was comparable. The complication/morbidity score was lower in the laser group (1.92 versus 3.48 (P $\left.\frac{1}{4} 0.04, \mathrm{CI}: 0.01,2\right)$ ). The long-term benefit was $50 \%$ and $36 \%$ in the laser and diathermy group, respectively. Ho: Yag laser treatment is equally efficacious but causes fewer complexities and morbidity than surface diathermy [64].

Sapci et al. addressed this problem by comparing three techniques: $\mathrm{CO} 2$ laser ablation, partial turbinectomy, and RFAIT. The study was conducted on three groups of 45 adult patients with nasal obstruction and stuffiness related to enlarged turbinates. Group A was treated with laser ablation, group $B$ was treated with radiofrequency tissue ablation, and group $C$ was the control group non-treated with surgical therapy. At 12 weeks after surgery, the nasal mucociliary transport time results were 
compared in the same patients. In patients on whom RFAIT and partial turbinectomy were applied, the average nasal mucociliary transport time was $10.33 \mathrm{~min}$, whereas it was $11.33 \mathrm{~min}$ on the partial turbinectomy side. Rhinomanometric measurements demonstrated a significant decrease in nasal resistances at 12 weeks on both sides in groups A and B. All three techniques were valid for the turbinate volumetric reduction, the Laser presented, compared to the other greater damage to the mucosa [54].

\subsection{Diode Laser}

The diode laser produces infrared light with a wavelength of $810 / 940 \mathrm{~nm}$ responsible for thermal reactions up to a depth of $5 \mathrm{~mm}$ [57].

Caffier's research group studied the use of diode lasers extensively: 42 patients were evaluated who obtained, after the procedure, a success rate of $88 \%$ at 6 months and $74 \%$ after 12 months from treatment [65].

In another work conducted by the same study group, the effects of turbinoplasty using diode lasers were analyzed in $40 \mathrm{AR}$ patients (20 patients with perennial pAR vs. 20 patients with seasonal sAR). Examinations were performed preoperatively and at follow-ups 1, 12, and 24 months after surgery, including physical parameters (rhinomanometry, video endoscopy, allergy tests) and subjective VAS scale. Throughout follow-up, objective rhinomanometry and subjective scores for nasal obstruction, rhinorrhea, sneezing, itching, and overall satisfaction gained significantly with time $(p<0.0005)$. The improvement was most remarkable for nasal obstruction, initially higher in pAR but more sustained in sAR. After 2 years, 30\% sAR and $40 \%$ pAR subjects had been receiving pharmacotherapy due to recurrent symptoms: the improvement was perpetuated two years after the surgical procedure [66].

Another recent paper confirmed the use of diode laser in 60 patients with AR resistant to medical therapy. In this descriptive cross-sectional study, there was a significant improvement in symptoms like nasal obstruction, nasal discharge, sneezing, and decreased sense of smell measured with the Visual Analogue scale [67].

\subsection{Potassium Titanyl Phosphate Laser (KTP)}

Potassium titanyl phosphate (KTP) Laser has a wavelength of $532 \mathrm{~nm}$. [68] The laser beam is effectively absorbed by pigments such as hemoglobin and melanin-producing localized coagulation, making it very effective, especially in highly vascularized tissues such as the turbinate [69-71].

Vijayakumar et al. evaluated the performance of laser KTP for the volumetric reduction of the turbinates in subjects with AR. Thirty patients were selected, SNOT22 and saccharine transit time (STT) were evaluated before surgery and at a follow-up at 1 week, 1 month, and 3 months. The patients showed meaningful differences in the symptoms $(p=0.0001)$ at each follow-up. Saccharin transit test at one month prolonged significantly $(p=0.0001)$, but at the third month, saccharin transit time returned to normal limits (17.96 $\mathrm{min})$ [71].

Another recent study compared the KTP laser with the diode laser [72]. This randomized controlled trial included 209 patients with ITH. Nasal Obstruction Symptom Evaluation (NOSE) score and STT were observed. Postoperatively, the median NOSE score was 50 in the diode group and 40 in the KTP group, and at three months, 15 in the diode group and five in the KTP group. KTP Laser registered a $93 \%$ increase in the NOSE score as compared to a $77 \%$ improvement in the diode laser group. On the other hand, both lasers altered the nose's mucociliary clearance for up to three months of postoperative follow-up. KTP laser was more productive than diode laser in improving the NOSE scores but with a slightly increased rate of complications in the early postoperative period [72].

\section{Conclusions}

Turbinates inferior hypertrophy is a clinical condition usually observed in allergic rhinitis (AR), in non-allergic rhinitis (NAR), and in anatomic-structural dysfunction of nasal cavities (septal deviation). 
Medical treatment with antihistamines, systemic decongestants, topical decongestants, or local corticosteroids often gives only mild relief for patients who use them. The surgical reduction of the lower turbinates is often required benefit in the medium to long term. A wide variety of surgical techniques have been described in the literature. These include total and partial turbinectomy, submucosal turbinectomy, submucosal resection with microdebrider, cryotherapy, and submucosal electrosurgery and turbinectomies using different types of lasers.

The perfect surgery for the lower turbinates should produce the least number of side effects and discomfort and protect the nose's physiological functions such as its humidification, the heating of the inspired air, and the respect of mucociliary clearance. The principal goal in turbinate surgery is to reduce the concal submucosal volume while protecting the integrity of the nasal mucosa.

When analyzing the advantages, disadvantages, and complications in the short- long term of the various surgical techniques used to treat turbinal hypertrophy, especially in allergic subjects, it is complicated to draw definitive conclusions.

An ideal study should meet the following criteria: the study should be prospective or comparative; patients should be randomly assigned to the study groups, and all should suffer from the same disease, avoiding comparing results in subjects with RA and NAR; preoperative and postoperative parameters should include the patient's symptoms (VAS score), functional tests (respiration, mucociliary transport, nasal defense, etc.), complications, and up to $3-5$ follow-up years. We realized it is difficult to meet all these requirements.

However, we all agree that only the studies of this type would really help us find answers to many more remaining questions.

Author Contributions: Conceptualization, A.M., M.D.L., and S.C.; methodology, C.G. and C.M.G.; software, E.P. and I.L.M.; validation, F.M., V.B., C.V., G.I., and C.R.; writing-original draft preparation, I.L.M., C.M.G., G.C., A.M., and D.L.M.; writing-review and editing, S.C. and A.M. All authors have read and agreed to the published version of the manuscript.

Funding: This research received no external funding.

Conflicts of Interest: The authors declare no conflict of interest.

\section{References}

1. Juniper, E.F. Impact of upper respiratory allergic diseases on quality of life. J. Allergy Clin. Immunol. 1998, 101, S386-S391. [CrossRef]

2. Lippert, B.M.; Werner, J.A. Nd: YAG-laserlichtinduzierte Nasenmuschelreduktion. Laryngorhinootologie 1996, 75, 523-528. [CrossRef]

3. Ottaviani, F.; Capaccio, P.; Cesana, B.M.; Manzo, R.; Peri, A. Argon plasma coagulation in the treatment of non-allergic hy-pertrophic inferior nasal turbinates. Am. J. Otolaryngol. 2003, 24, 306-310. [CrossRef]

4. Cocuzza, S.; Maniaci, A.; Di Luca, M.; La Mantia, I.; Grillo, C.; Spinato, G.; Motta, G.; Testa, D.; Ferlito, S. Long-term results of nasal surgery: Comparison of mini-invasive turbinoplasty. J. Biol. Regul. Homeost. Agents 2020, 34, 1203-1208.

5. Goyal, P.; Hwang, P. Surgery of the septum and turbinates. In Rhinology: Diseases of the Nose, Sinuses, and Skull Base; Kennedy, D.P.H., Ed.; Thieme: New York, NY, USA, 2012.

6. Hansen, I.; Klimek, L.; Mösges, R.; Hörmann, K. Mediators of inflammation in the early and the late phase of allergic rhinitis. Curr. Opin. Allergy Clin. Immunol. 2004, 4, 159-163. [CrossRef] [PubMed]

7. Dullaers, M.; De Bruyne, R.; Ramadani, F.; Gould, H.J.; Gevaert, P.; Lambrecht, B.N. The who, where, and when of IgE in allergic airway disease. J. Allergy Clin. Immunol. 2012, 129, 635-645. [CrossRef]

8. Nurieva, R.I.; Liu, X.; Dong, C. Yin-Yang of costimulation: Crucial controls of immune tolerance and function. Immunol. Rev. 2009, 229, 88-100. [CrossRef] [PubMed]

9. Mori, S.; Fujieda, S.; Igarashi, M.; Fan, G.K.; Saito, H. Submucous turbinectomy decreases not only nasal stiffness but also sneezing and rhinorrhea in patients with perennial allergic rhinitis. Clin. Exp. Allergy 1999, 29, 1542-1548. [CrossRef] 
10. Passàli, D.; Anselmi, M.; Lauriello, M.; Bellussi, L. Treatment of Hypertrophy of the Inferior Turbinate: Long-Term Results in 382 Patients Randomly Assigned to Therapy. Ann. Otol. Rhinol. Laryngol. 1999, 108, 569-575. [CrossRef] [PubMed]

11. Serrano, E.; Percodani, J.; Yardeni, E.; Lombard, L.; Laffitte, F.; Pessey, J.J. The holmium:YAG laser for treatment of inferior turbinate hypertrophy. Rhinol. J. 1998, 36, 77-80.

12. Elwany, S.; Abel Salaam, S. Laser surgery for allergic rhinitis: The effect on seromucinous glands. Otolaryngol Head Neck Surg. 1999, 120, 742-744. [CrossRef] [PubMed]

13. Seidman, M.D.; Gurgel, R.K.; Lin, S.Y.; Schwartz, S.R.; Baroody, F.M.; Bonner, J.R.; Dawson, D.E.; Dykewicz, M.S.; Hackell, J.M.; Han, J.K.; et al. Clinical practice guideline: Allergic rhinitis. Otolaryngol. Head Neck Surg. 2015, 152, S1-S43. [CrossRef]

14. Lin, H.-C.; Lin, P.-W.; Friedman, M.; Chang, H.-W.; Su, Y.-Y.; Chen, Y.-J.; Pulver, T.M. Long-term Results of Radiofrequency Turbinoplasty for Allergic Rhinitis Refractory to Medical Therapy. Arch. Otolaryngol. Head Neck Surg. 2010, 136, 892. [CrossRef] [PubMed]

15. Mladina, R.; Risavi, R.; Subaric, $\mathrm{M} . \mathrm{CO}_{2}$ laser anterior turbinectomy in the treatment of non-allergic vasomotor rhinopathia. A prospective study upon 78 patients. Rhinol. J. 1991, 29, 267-271.

16. Cassano, M.; Del Giudice, A.M.; Russo, G.; Russo, L.; Ciprandi, G. The Role of Nasal Cytology in the Management of Inferior Turbinate Hypertrophy. Int. J. Immunopathol. Pharmacol. 2013, 26, 207-215. [CrossRef] [PubMed]

17. Passàli, D.; Passàli, F.M.; Passàli, G.C.; Damiani, V.; Bellussi, L. Treatment of Inferior Turbinate Hypertrophy: A Randomized Clinical Trial. Ann. Otol. Rhinol. Laryngol. 2003, 112, 683-688. [CrossRef]

18. Wise, S.K.; Lin, S.Y.; Toskala, E.; Orlandi, R.R.; Akdis, C.A.; Alt, J.A.; Azar, A.; Baroody, F.M.; Bachert, C.; Canonica, G.W.; et al. International Consensus Statement on Allergy and Rhinology: Allergic Rhinitis. Int. Forum Allergy Rhinol. 2018, 8, 108-352. [CrossRef]

19. Mol, M.K.; Huizing, E.H. Treatment of inferior turbinate pathology: A review and critical evaluation of the different techniques. Rhinology 2000, 38, 157-166.

20. Joniau, S.; Wong, I.; Rajapaksa, S.; Carney, S.A.; Wormald, P.-J. Long-Term Comparison Between Submucosal Cauterization and Powered Reduction of the Inferior Turbinates. Laryngoscope 2006, 116, 1612-1616. [CrossRef] [PubMed]

21. Moore, G.F.; Freeman, T.J.; Ogren, F.P.; Yonkers, A.J. Extended Follow-Up of Total Inferior Turbinate Resection for Relief of Chronic Nasal Obstruction. Laryngoscope 1985, 95, 1095-1099. [CrossRef] [PubMed]

22. Talmon, Y.; Samet, A.; Gilbey, P. Total Inferior Turbinectomy: Operative Results and Technique. Ann. Otol. Rhinol. Laryngol. 2000, 109, 1117-1119. [CrossRef] [PubMed]

23. Huizing, E.H.; de Groot, J.A.M. Surgical of the nasal cavity. In Functional Reconstructive Nasal Surgery; Thieme Medical Publishers: New York, NY, USA, 2003.

24. Mori, S.; Fujieda, S.; Yamada, T.; Kimura, Y.; Takahashi, N.; Saito, H. Long-Term Effect of Submucous Turbinectomy in Patients With Perennial Allergic Rhinitis. Laryngoscope 2002, 112, 865-869. [CrossRef]

25. Liu, C.M.; Tan, C.D.; Lee, F.P.; Lin, K.N.; Huang, H.M. Microdebrider-assisted versus radiofrequency-assisted inferior tur-binoplasty. Laryngoscope 2009, 119, 414-418. [CrossRef]

26. Huang, T.-W.; Cheng, P.-W. Changes in Nasal Resistance and Quality of Life After Endoscopic Microdebrider-Assisted Inferior Turbinoplasty in Patients with Perennial Allergic Rhinitis. Arch. Otolaryngol. Head Neck Surg. 2006, 132, 990-993. [CrossRef] [PubMed]

27. Lee, J.Y. Efficacy of intra- and extraturbinal microdebrider turbinoplasty in perennial allergic rhinitis. Laryngoscope 2013, 123, 2945-2949. [CrossRef] [PubMed]

28. Chen, Y.-L.; Tan, C.-T.; Huang, H.-M. Long-Term Efficacy of Microdebrider-Assisted Inferior Turbinoplasty With Lateralization for Hypertrophic Inferior Turbinates in Patients With Perennial Allergic Rhinitis. Laryngoscope 2008, 118, 1270-1274. [CrossRef]

29. Elwany, S.; Gaimaee, R.; Fattah, H.A. Radiofrequency bipolar submucosal diathermy of the inferior turbinates. Am. J. Rhinol. 1999, 13, 145-149. [CrossRef] [PubMed]

30. Fradis, M.; Danino, J.; Gaitini, L.; Gershinski, M.; Malatskey, S.; Golz, A.; Goldsher, M.; Armush, W. Inferior Turbinectomy versus Submucosal Diathermy for Inferior Turbinate Hypertrophy. Ann. Otol. Rhinol. Laryngol. 2000, 109, 1040-1045. [CrossRef]

31. Lippert, B.M.; Werner, J.A. Comparison of carbon dioxide and neodymium: Yttrium-aluminium-garnet lasers in surgery of the inferior turbinate. Ann. Otol. Rhinol. Laryngol. 1997, 106, 1036-1042. [CrossRef] 
32. Meredith, G.M. Surgical reduction of hypertrophied inferior turbinates: A comparison of electrofulguration and partial re-section. Plast. Reconstr. Surg. 1988, 81, 891-899. [CrossRef] [PubMed]

33. Sharmila, D. Comparative Study of Response Through Reduction in the Size of Hypertrophied Inferior Turbinate Causing Nasal Obstruction by Different Surgical Modalities: A Prospective Study. Indian J. Otolaryngol. Head Neck Surg. 2015, 67, 56-59.

34. Golding-Wood, P.H. Observations on Petrosal and Vidian Neurectomy in Chronic Vasomotor Rhinitis. J. Laryngol. Otol. 1961, 75, 232-247. [CrossRef]

35. Kobayashi, T.; Hyodo, M.; Nakamura, K.; Komobuchi, H.; Honda, N. Resection of peripheral branches of the posterior nasal nerve compared to conventional posterior neurectomy in severe allergic rhinitis. Auris Nasus Larynx 2012, 39, 593-596. [CrossRef] [PubMed]

36. Kawamura, S.; Asako, M.; Momotani, A.; Ikeda, H.; Kubo, N.; Yamashita, T. Submucosal turbinectomy with posterior-superior nasal nerurectomy for patients with allergic rhinitis. Pract. Oto Rhino Laryngol. 2000, 93, 367-372. [CrossRef]

37. Kikawada, T. Endoscopic posterior nasal neurectomy: Analternative to vidian neurectomy. Oper. Tech. Otolaryngol. 2007, 18, 297-301. [CrossRef]

38. Nagalingeswaran, A.; Kumar, R.D. Newer Surgical Options for Nasal Allergy. Indian J. Otolaryngol. Head Neck Surg. 2019, 72, 133-139. [CrossRef]

39. Bergler, W.F. Argon plasma coagulation (APC) surgery in otorhinolaryngology. Surg. Technol. Int. 2003, 11, 79-84.

40. Bergler, W.F.; Sadick, H.; Hammerschmitt, N.; Oulmi, J.; Hörmann, K. Long-Term Results of Inferior Turbinate Reduction With Argon Plasma Coagulation. Laryngoscope 2001, 111, 1593-1598. [CrossRef]

41. Gierek, T.; Jura-Szołtys, E. Long-term results after argon plasma coagulation (APC) inferior turbinates reduction. Otolaryngol. Pol. 2007, 61, 63-68. [CrossRef]

42. Jura-Szołtys, E.; Ficek, R.; Ficek, J.; Markowski, J.; Chudek, J. Bronchial asthma control after argon plasma coagulation turbinectomy in patients with chronic rhinitis. Eur. Arch. Otorhinolaryngol. 2014, 271, 1581-1587. [CrossRef] [PubMed]

43. Bhandarkar, N.D.; Smith, T.L. Outcomes of surgery for inferior turbinate hypertrophy. Curr. Opin. Otolaryngol. Head Neck Surg. 2010, 18, 49-53. [CrossRef]

44. Banhiran, W.; Tantilipikorn, P.; Metheetrairut, C.; Assanasen, P.; Bun-nag, C. Quality of life in patients with chronic rhinitis after radiofrequency inferior turbinate reduction. J. Med. Assoc. Thai 2010, 93, 950-960.

45. Cukurova, I.; Demirhan, E.; Cetinkaya, E.; Yigitbasi, O.G. Long-term clinical results of radiofrequency tissue volume reduction for inferior turbinate hypertrophy. J. Laryngol. Otol. 2011, 125, 1148-1151. [CrossRef]

46. Türk, B.; Korkut, A.Y.; Kaya, K.S.; Salepçi, E.; Coşkun, B.U.; Turgut, S. Results of radiofrequency ablation of inferior turbinate hypertrophy in allergic and non-allergic rhinitis patients. Med Bull. Sisli Hosp. 2018, 52, 296-301. [CrossRef]

47. De Corso, E.; Bastanza, G.; Di Donfrancesco, V.; Guidi, M.; Sbarra, G.M.; Passali, G.; Poscia, A.; De Waure, C.; Paludetti, G.; Galli, J. Radiofrequency volumetric inferior turbinate reduction: Long-term clinical results. Acta Otorhinolaryngol. Ital. 2016, 36, 199-205.

48. Hytönen, M.L.; Bäck, L.J.J.; Malmivaara, A.V.; Roine, R.P. Radiofrequency thermal ablation for patients with nasal symptoms: A systematic review of effectiveness and complications. Eur. Arch. Otorhinolaryngol. 2009, 266, 1257-1266. [CrossRef] [PubMed]

49. Siméon, R.; Soufflet, B.; Delacour, I.S. Coblation turbinate reduction in childhood allergic rhinitis. Eur. Ann. Otorhinolaryngol. Head Neck Dis. 2010, 127, 77-82. [CrossRef]

50. Ye, T.; Zhou, B. Update on surgical management of adult inferior turbinate hypertrophy. Curr. Opin. Otolaryngol. Head Neck Surg. 2015, 23, 29-33. [CrossRef] [PubMed]

51. Fukutake, T.; Yamashita, T.; Tomoda, K.; Kumazawa, T. Laser Surgery for Allergic Rhinitis. Arch. Otolaryngol. Head Neck Surg. 1986, 112, 1280-1282. [CrossRef]

52. Janda, P.; Sroka, R.; Baumgartner, R.; Grevers, G.; Leunig, A. Laser treatment of hyperplastic inferior nasal turbinates: A review. Lasers Surg. Med. 2001, 28, 404-413. [CrossRef] [PubMed]

53. Chang, C.D.; Ries, W.R. Surgical treatment of the inferior turbinate: New techniques. Curr. Opin. Otolaryngol. Head Neck Surg. 2004, 12, 53-57. [CrossRef] [PubMed] 
54. Sapçi, T.; Sahin, B.; Karavus, A.; Akbulut, U.G. Comparison of the Effects of Radiofrequency Tissue Ablation, CO2 Laser Ablation, and Partial Turbinectomy Applications on Nasal Mucociliary Functions. Laryngoscope 2003, 113, 514-519. [CrossRef] [PubMed]

55. Testa, D.; Motta, G.; Galli, V.; Iovine, R.; Guerra, G.; Marenzi, G.; Testa, B. Outcome assessment in patients with chronic obstructive rhinitis $\mathrm{CO}_{2}$ laser treated. Acta Otorhinolaryngol. Ital. 2006, 26, 32-37. [PubMed]

56. Takeno, S.; Ishino, T.; Osada, R.; Yajin, K. Laser surgery of the inferior turbinate for allergic rhinitis with seasonal exacerbation: An acoustic rhinometry study. Ann. Otol. Rhinol. Laryngol. 2003, 112, 455-460. [CrossRef] [PubMed]

57. Parkin, J.L.; Dixon, J.A. Laser Photocoagulation in Hereditary Hemorrhagic Telangiectasia. Otolaryngol. Neck Surg. 1981, 89, 204-208. [CrossRef] [PubMed]

58. Werner, J.A.; Rudert, H. Der Einsatz des Nd: YAG-Lasers in der Hals- Nasen-Ohrenheilkunde. HNO 1992, 40, 248-258.

59. Lippert, B.M.; Werner, J.A. Die Behandlung der hypertrophen unteren Nasenmuschel. Teil 1. HNO 2000, 48, 170-181. [CrossRef]

60. Olthoff, A.; Martin, A.; Liebmann, F. Nd: YAG-laser treatment of the lower turbinates with contact in hyperreflexic and allergic rhinopathy. Laryngorhinootology 1999, 78, 740-743.

61. Vagnetti, A.; Gobbi, E.; Algieri, G.M.; D’Ambrosio, L. Wedge Turbinectomy: A New Combined Photocoagulative Nd:YAG Laser Technique. Laryngoscope 2000, 110, 1034-1036. [CrossRef]

62. Janda, P.; Sroka, R.; Betz, C.S.; Baumgartner, R.; Leunig, A. Comparison of laser induced effects on hyperplastic inferior nasal turbinates by means of scanning electron microscopy. Lasers Surg. Med. 2002, 30, 31-39. [CrossRef]

63. Sroka, R.; Janda, P.; Killian, T.; Vaz, F.; Betz, C.S.; Leunig, A. Comparison of long term results after Ho:YAG and diode laser treatment of hyperplastic inferior nasal turbinates. Lasers Surg. Med. 2007, 39, 324-331. [CrossRef]

64. Rejali, S.; Upile, T.; McLellan, D.; Bingham, B. Inferior turbinate reduction in children using Holmium YAG laser?a clinical and histological study. Lasers Surg. Med. 2004, 34, 310-314. [CrossRef] [PubMed]

65. Caffier, P.P.; Frieler, K.; Scherer, H.; Sedlmaier, B.; Göktas, Ö. Rhinitis Medicamentosa: Therapeutic Effect of Diode Laser Inferior Turbinate Reduction on Nasal Obstruction and Decongestant Abuse. Am. J. Rhinol. 2008, 22, 433-439. [CrossRef]

66. Caffier, P.P.; Scherer, H.; Neumann, K.; Lück, S.; Enzmann, H.; Haisch, A. Diode laser treatment in therapy-resistant allergic rhinitis: Impact on nasal obstruction and associated symptoms. Lasers Med. Sci. 2010, 26, 57-67. [CrossRef]

67. Gupta, P.; Kc, T.; Regmi, D. Diode Laser Turbinate Reduction in Allergic Rhinitis: A Cross-sectional Study. J. Nepal Med. Assoc. 2018, 56, 949-952. [CrossRef]

68. Supiyaphun, P.; Aramwatanapong, P.; Kerekhanjanarong, V.; Sastarasadhit, V. KTP laser inferior turbinoplasty: An alternative procedure to treat the nasal obstruction. Auris Nasus Larynx 2003, 30, 59-64. [CrossRef]

69. Wang, H.K.; Tsai, Y.H.; Wu, Y.Y.; Wang, P.C. Endoscopic potassium titanyl phosphate laser treatment for hypertrophic inferior turbinate. Photomed. Laser Surg. 2004, 22, 173-176. [CrossRef] [PubMed]

70. Kunachak, S.; Kulapaditharom, B.; Prakunhungsit, S. Minimally invasive KTP laser treatment of perennial allergic rhinitis: A preliminary report. J. Otolaryngol. 2000, 29, 143.

71. Vijayakumar, S.; Divakaran, S.; Parida, P.K.; Gopalakrishnan, S. Potassium Titanyl Phosphate Laser Turbinate Reduction in the Management of Allergic Inferior Turbinate Hypertrophy: Our Experience. Allergy Rhinol. 2016, 7, 29-33. [CrossRef] [PubMed]

72. Saxena, S.K.; Ravichandran, S.P.; Ramasamy, K.; Parida, P.K.; Alexander, A.; Ganesan, S. Comparison of efficacy of potassium titanyl phosphate laser \& diode laser in the management of inferior turbinate hypertrophy: A randomized controlled trial. Indian J. Med. Res. 2020, 151, 578-584. [CrossRef]

Publisher's Note: MDPI stays neutral with regard to jurisdictional claims in published maps and institutional affiliations. 